\title{
Taxonomically Significant Group Antigens in Rhizobium
}

\author{
By J. M. VINCENT AND BEVERLEY HUMPHREY \\ School of Microbiology, University of New South Wales, \\ P.O. Box I, Kensington, N.S.W. 2033, Australia
}

\section{(Accepted for publication 24 September 1970)}

Earlier studies of the antigenic determinants of Rhizobium were almost entirely concerned with agglutinogens and revealed considerable strain specificity, the recognition of which was enhanced by a distinction between flagellar and somatic antigens (Bushnell \& Sarles, I939; Vincent, I94I, I942; Kleczkowski \& Thornton, I944; Purchase, Vincent \& Ward, I95I; Means, Johnson \& Date, I964). In some cases this specificity depended on complex patterns of shared antigens, in others on complete non-cross reactivity between strains that belonged to the same species. Agglutination could not therefore be depended on for the recognition of species or groups of species of rhizobia. On the other hand, the technique has proved valuable for the definition of serotypes and the labelling of strains used for experimental purposes.

Some attention has recently been given to the demonstration of soluble antigens by the gel-diffusion technique, using either the bacteria or isolated fractions as source of antigen (Dudman, 1964; Humphrey \& Vincent, 1965; 1969 $a, b$; Scheffler \& Louw, 1967; Failly \& Blachère, I968; Škrdtela, 1969). This technique can be used for the recognition of serotypes within a species, but this may be complicated if additional antigens are released by mechanical breakage of the bacteria, or, in a less-controlled fashion, as a result of leakage from bacteria in calcium-deficient cultures (Humphrey \& Vincent, 1965), or in old cultures, or from bacteria that may have been damaged by lyophilization or freezing and thawing.

The occurrence of what appeared to be internal antigens suggested the possibility that they might reveal a group reactivity not seen in the more specific antigens associated with the bacterial surface. Evidence for this was referred to briefly in our earlier report (Humphrey \& Vincent, 1965) and is supported by the more comprehensive tests reported in the present paper.

Antisera were developed in rabbits against two strains of Rhizobium trifolii (su 329 (TA I) and SU 297/3I) and a strain of R. meliloti (U 45) grown in a defined liquid medium (Vincent, 1962). The suspensions were injected at first intramuscularly with Freund's complete adjuvant and later intravenously without adjuvant, following the detailed procedure already described (Humphrey \& Vincent, 1965). Such antisera had an agglutination titre of 6400 and when diffused against washed homologous bacteria, broken in a Mickle disintegrator, revealed several groups of lines which have been labelled $a, b$ and $c$ in order from the antigen well towards the antiserum well. The $a$ lines of $R$. trifolii have been identified as being due to specific agglutinating antigen (Humphrey \& Vincent, $1969 b$ ), the remainder, not found when young intact rhizobia are used in the antigen well, can be attributed to 'internal' antigens. $R$. meliloti seems to provide a similar array of specific agglutinating and non-specific internal antigens.

Antisera differ in the clarity and further splitting of the $b$ and $c$ lines. An antiserum 
to a 2 I day culture of Rhizobium trifolii su 329 permitted clear recognition of two lines within $b$ and $c\left(b_{1}, b_{2}, c_{1}, c_{2}\right)$ whereas other antisera prepared against 3 day cultures of the same strain or $R$. trifolii SU 297/3 I did not permit this degree of further resolution although the $b$ and $c$ lines were quite clear. Antiserum to a 3 day culture of $R$. meliloti $\mathrm{U} 45$ showed besides strain specific $a$ positioned lines, an array of seven lines in the $b$ and $c$ positions. The development of antibodies to internal antigens was not dependent on breakage of the bacteria before injection provided the whole bacteria were mixed with adjuvant and the intramuscular route was used. Differences between individual rabbits seemed to be more important in determining the degree of resolution within the major lines. A series of intravenous injections alone, whilst producing a high agglutinin titre, did not appear to be as satisfactory for the production of antibody to internal antigens.

Twenty-nine strains of fast-growing rhizobia (Rhizobium trifolii, ten; R. leguminosarum, seven; $R$. phaseoli, one; $R$. meliloti, nine, and one each of a fast Lotus and Leucaena culture), nine slow growers ( $R$. lupini, three; $R$. japonicum, one; cowpea rhizobia, four, and a slow Lotus rhizobium) and four Agrobacteria (Agrobacterium radiobacter, two; $A$. tumefaciens, two), were used in the present investigation. A small collection of other non-rhizobia was also included (representative Escherichia, Aerobacter, Salmonella, Pseudomonas, Flavobacterium and Bacillus). Rhizobia and the agrobacteria used for the demonstration of internal antigens were grown as shaken cultures in yeast extract liquid medium (Fred, Baldwin \& McCoy, 1932) at $26^{\circ}$ for 3 days (fast growers) or 8 to Io days (slow growers). Identical results were obtained when the organisms were cultured in the defined medium, or with the yeast extract contained within the dialysis sac. Other bacteria were harvested from the usual meat infusion agar.

In tests of this kind, the amount of bacterial suspension used as testing antigen is important for the detection and resolution of lines. Too high a concentration can be as misleading as too low a concentration. For example, the $c$ lines appeared as a diffuse band at $20 \mathrm{mg}$. $/ \mathrm{ml}$. (dry wt) but at $5 \mathrm{mg}$. $/ \mathrm{ml}$. were resolved into two clear lines with some antisera or one clear line with others. No single concentration of antigen suspension gave clear resolution of all lines. Comparisons were made, using $0 \cdot 1 \mathrm{ml}$./well, of two concentrations ( 5 and $20 \mathrm{mg}$. $/ \mathrm{ml}$.) with patterns that permitted direct comparisons with the homologous reaction.

All except one (an ineffective u.v.-induced mutant of Rhizobium meliloti) of the fast-growing rhizobia and the agrobacteria revealed clear internal antigen lines with $R$. trifolii antisera. The patterns revealed using the more highly resolving antiserum to strain su 329 are shown in Table 1 . Similar tests with antiserum to $R$. meliloti U 45 confirmed and complemented the evidence obtained with $R$. trifolii antisera. All of the fast growers gave clear internal lines. Lines shared with the homologous condition were greatest among the $R$. meliloti, less with three of the four agrobacteria and the mutant $R$. meliloti, Sa Iом, and least with $R$. trifolii, $R$. leguminosarum, $R$. phaseoli, the faster lotus strain and the other agrobacterium. All the slow-growing rhizobia were again negative.

The results are interesting both because they provide a means for quick recognition of fast-growing rhizobia and because of the support they offer other taxonomic evidence showing close relationship between Rhizobium trifolii, $R$. leguminosarum and $R$. phaseoli, some, but less close, relationship between these and $R$. meliloti, an evident 
relationship between the latter and agrobacteria, and the distinctiveness of the slowgrowing rhizobia (Graham, I964; Heberlein, de Ley \& Tijtgat, I967; t'Mannetje, I967; Kern, 1968; Moffett \& Colwell, 1968; Wu, Gregory \& Hauser, I968; Yao \& Vincent, 1969). Common antigens have also been reported amongst strains of $R$. japonicum not sharing an agglutinogen or the specific gel-diffusion line that would occupy the $a$ position (Škrdtela, 1969). The same phenomenon appears to be involved.

On the other hand, our results contain a warning as to the confusion that could arise in strain identification by gel-diffusion technique if the specificity of the surface antigens were to be confused by the undetected release of internal 'group' antigens in old or mishandled cultures.

\section{Table I. Patterns of internal antigens observed with Rhizobium trifolii (SU329) antiserum}

The fast-growing strains are divided into two groups $(a, b)$ using established characteristics of these species and the internal antigen lines found in the present work.

Line identification

Fast-growing strains

(a) R. trifolii (8)*
R. leguminosarum (6)
R. phaseoli (I)
R. trifolii (2)
R. leguminosarum (I)

(b) R. meliloti (6)

A. tumefaciens (I)

A. radiobacter (I)

Leucaena rhizobium (1)

A. tumefaciens (I)

$A$. radiobacter (I)

$\left.\begin{array}{l}\text { R. meliloti (2) } \\ \text { Lotus rhizobium (su 343) } \dagger\}\end{array}\right\}$

R. meliloti (I) :

Slow-growing strains

R. lupini (3)

R. japonicum (I)

Cowpea rhizobia (4)

Lotus rhizobium (I)§

Other bacteria: non-rhizobia

$\overbrace{b_{1}}^{b_{2}} c_{1} \quad c_{2}$

$+\quad+$

$+\quad+$

$+\quad-$

$+$

$-\quad+$

$+$

$-$

$+$

$+\quad+$

$+2+$

Number of strains showing pattern given in parentheses.

$\dagger$ Fast-growing lotus strain.

$\ddagger$ Ultraviolet-induced ineffective mutant (Sa IO M) of Sa Io (Failly \& Blachère, 1968). The parent strain gave $b_{1}$ and $c_{1}$ lines with antiserum to $R$. trifolii SU 329.

$\S$ Slow-growing lotus strain.

Finally, it should be noted that the results we have reported were obtained with preparations from washed deposited bacteria. We see no reason for believing that the group antigenic reactions we have reported depend on extracellular gum, which, in our experience with Rhizobium trifolii, appears to be inactive at concentrations far in excess of what would occur in the suspensions of washed bacteria we have used.

This work has been supported by the Australian Research Grants Committee, the Wheat Industry Research Council, and the Rural Credits Division of the Reserve Bank of Australia. The skilled assistance of Mrs B. Netting and Mrs S. Wake is gratefully acknowledged. 


\section{REFERENCES}

Bushnell, U. A. \& SARLES, W. B. (1939). Investigations upon the antigenic relationships of the root nodule bacteria of the soybean, cowpea and lupine cross inoculation groups. Journal of Bacteriology 38, 40I-4IO.

Dudman, W. F. (I964). Immune diffusion analysis of the extracellular soluble antigens of two strains of Rhizobium meliloti. Journal of Bacteriology 88, 782-793.

FaIlly, C. \& BlachèRe, H. (I968). Identité immunochimique des certains polysaccharides extracellulaires chez diverses espèces de Rhizobium. Canadian Journal of Microbiology 14, 247-25I.

Fred, E. B., Baldwin, I. L. \& MCCoy, E. (1932). Root-nodule Bacteria and Leguminous Plants. University of Wisconsin Studies in Science no. 5, Madison.

GraHAM, P. H. (I964). The application of computer techniques to the taxonomy of the root-nodule bacteria of legumes. Journal of General Microbiology 35, 5I I-5I 7 .

Heberlein, G. T., De Ley, J. \& Tistgat, R. (1967). Deoxyribonucleic homology and taxonomy of Agrobacterium, Rhizobium and Chromobacterium. Journal of Bacteriology 94, I I6-1 24.

Humphrey, B. A. \& Vincent, J. M. (1965). The effect of calcium nutrition on the production of diffusible antigens of Rhizobium trifolii. Journal of General Microbiology 41, I09-1 I8.

Humphrey, R. A. \& VinCENT, J. M. (1969a). Correlation between surface charge density of whole cells and electrophoretic movement of isolated somatic antigen of Rhizobium trifolii. Journal of Bacteriology 98, 845-846.

Humphrey, B. A. \& VinCENT, J. M. (1969 b). The somatic antigens of two strains of Rhizobium trifolii. Journal of General Microbiology 59, 4I I-425.

Kern, H. (1968). Beitrage zur Taxonomie der Rhizobiaceae. Archiv für Mikrobiologie 63, 278-29I.

Kleczkowski, A. \& Thornton, H. G. (I944). A serological study of root-nodule bacteria from pea and clover inoculation groups. Journal of Bacteriology 48, 66I-672.

T'MANNETJE, L. (1967). A re-examination of the taxonomy of the genus Rhizobium and related genera using a numerical analysis. Antonie van Leeuwenhoek 33, 477-49I.

Means, U. M., Johnson, H. W. \& Date, R. A. (1964). Quick serological method of classifying strains of Rhizobium japonicum in nodules. Journal of Bacteriology 87, 547-553.

Moffett, M. L. \& Colwell, R. R. (1968). Adansonian analysis of the Rhizobiaceae. Journal of General Microbiology 5I, 245-266.

Purchase, H. F., Vincent, J. M. \& Ward, L. M. (I95I). Serological studies of the root-nodule bacteria. IV. Further analysis of isolates from Trifolium and Medicago. Proceedings of the Linnean Society of New South Wales 76, I-6.

SCheffler, J. G. \& Louw, H. A. (1967). The serological characteristics of the clover rhizobia in the soils of the Stellenbosch district. South African Journal of Agricultural Science 10, I6I-174.

ŠrotelA, V. (I969). Serological analysis of eleven strains of Rhizobium japonicum. Antonie van Leeuwenhoek 35, 77-83.

VINCENT, J. M. (I94 r). Serological studies of the root-nodule bacteria. I. Strains of Rhizobium meliloti. Proceedings of the Linnean Society of New South Wales 66, I45-154.

VINCENT, J. M. (1942). Serological studies of the root-nodule bacteria. II. Strains of Rhizobium trifolii. Proceedings of the Linnean Society of New South Wales 67, 82-86.

VINCENT, J. M. (1962). Influence of calcium and magnesium on the growth of Rhizobium. Journal of General Microbiology 28, 653-663.

Wu, L., Gregory, K. F. \& HAuSER, M. M. (1968). DNA homologies in Rhizobium species. Bacteriological Proceedings 68, I9-20.

YAO, P. Y. \& VINCENT, J. M. (1969). Host specificity in the root hair 'curling factor' of Rhizobium spp. Australian Journal of Biological Sciences 22, 413-423. 